\title{
Clinical Approach for Evaluation and Management of Disorders of Sex Development
}

\author{
Najya A. Attia ${ }^{1}$ \\ 1. King Abdulaziz Medical City.Pediatric Department. Endocrine unite \\ King Saud bin Abdulaziz University for Health Sciences, Jeddah, Saudi Arabia
}

\section{ARTICLE INFO}

\section{Corresponding Author:}

\author{
Najya A. Attia \\ King Abdulaziz Medical City. \\ Pediatric Department. Endocrine \\ unite \\ King Saud bin Abdulaziz University \\ for Health Sciences, Jeddah, Saudi
}

Keywords:genitalia; disorders of sex development; sex assignment.

\begin{abstract}
"It's a boy" and "It's a girl" are words that are heard every second of every day all around the world. However, it is very distressing when the birth attendants are unable to make such a pronouncement because of disorders of sex development (DSD). DSD are congenital conditions associated with an atypical development of chromosomal, gonadal or anatomical sex. Normal sex development progresses in steps from conception to the complete development of the fetal external genitalia; any disturbance in any of these steps can lead to DSD. Ambiguous genitalia are the most common type of DSD and it is a challenging clinical diagnosis for the pediatric endocrinologist. A newborn baby with ambiguous genitalia is often a surprise for both the medical team and the parents, frequently described as an emergency. The condition needs a special approach in terms of counseling the parents appropriately, evaluation and management. The Chicago Conference (2006) recommended new nomenclature and a classification for DSD, as the old nomenclature was confusing for doctors and parents, and sometimes pejorative. The new classification is based on karyotyping and gonadal structure, improving understanding of the underlying pathogenic mechanisms. The rapid progression of genetic diagnosis of DSD using advanced techniques such as next-generation sequencing (NGS) allows more appropriate diagnosis and genetic counseling for families.

The focus of the article is a review of normal sex development, DSD classification, clinical approach, genetic assessment, sex assignment, surgical management and risk of germ cell tumor development.
\end{abstract}

\section{INTRODUCTION}

\section{Normal sex development and differentiation}

Sex differentiation is a complex phenomenon that follows five steps: 1-Genetic sex, the conjugation of a sperm and the ovum gives rise to the fertilized egg, which has either a $46, \mathrm{XY}$ or 46,XX chromosome (1). 2-Formation of undifferentiated structures, during the first six weeks of gestation the male and female fetus develops similar sex elements, which consist of the following potential structures: I) The gonadal ridge which develops in the testis or ovary. II) Germ cells, which eventually develop into spermatocytes or oocytes. III) Two sets of internal sex ducts (Wolffan ducts in males and Mullerian ducts in females). IV) External genitalia including the genital tubercle, urethral folds, labioscrotal folds and urogenital sinus. 3-Gonadal differentiation, the bipotential gonad develops into testis in the presence of a Y chromosome, which carries the SRY gene (Sex-determining Region Y) responsible for testicular formation. In the absence of a $\mathrm{Y}$ chromosome or SRY gene, the gonad develops into an ovary (2). 4-Gonadal hormones, at 7 weeks of gestation the testis secrete two hormones, testosterone and antiMüllerian hormone (AMH). The testosteroneis produced by the Leydig cells of the fetal testes and plays an essential role in the differentiation of Wolffian ducts to the epididymis, vas deferens and seminal vesicle. The $\mathrm{AMH}$, on the other hand, is secreted by the Sertoli cells of the fetal testes and is responsible for the regression of Müllerian ducts. In females, the Müllerian ducts develop spontaneously into fallopian tubes, uterus and upper third of the vagina and the Wolffian ducts disappear (3).

5-Phenotypic sex differentiation, the cells of the external genitalia of the male fetus has the ability to metabolize testosterone to dihydrotestosteron (DHT), which is 
more potent than testosterone and induces masculinization of external genitalia at about 9-12 weeks gestation. In a male fetus, the genital tubercle lengthens and thickens to form the penis, the urethral folds grow to become the penile urethra and the genital swellings enlarge to form the scrotal swelling which fuses in the midline to form the scrotum (4). In female fetuses, the absence of circulating testosterone allows the genital tubercle to develop into the clitoris, the urethral folds into the labia minora and the genital swelling into the labia majora.

\section{Nomenclature and classification of DSD}

The preexisting nomenclature of DSD (Table 1) such as intersex, sex reversal, pseudohermaphroditism and hermaphroditism was pejorative and confusing to parents, patients and doctors. As a consequence, a re-examination of DSD nomenclature and different classifications took place. In 2006, international experts in pediatric endocrinology met at the Chicago Conference under the auspices of the European Society for Pediatric Endocrinology and the Pediatric Endocrine Society and recommended new nomenclature (Table 1) for DSD, which was defined as "congenital conditions in which the development of chromosomal, gonadal, or anatomic sex is atypical" $(5,6)$. This definition is wide and includes any disorder that results in abnormal sex differentiation.

The current nomenclature and classifications (Table 1) are clear, understandable for physicians, patients and their families, and provide information regarding the patient's chromosome and gonadal structure, but is not very specific regarding etiology and depend on the physician's approach and facilities for diagnosis.

Table 1. Revised nomenclature
Previous

Current

Female

pseudohermaphrodite

Male

pseudohermaphrodite

True hermaphrodite

XX male

$X Y$ sex reversal
Intersex
Disorders of sex development

46XX DSD

46XY DSD

Ovotesticular DSD

46XX testicular

DSD

46XYcompletegonadal

dysgenesis

\section{Multidisciplinary team}

The best way to approach DSD is through a multidisciplinary team, which includes a neonatologist, endocrinologist, pediatric surgeon, psychologist and other ad hoc members (7). The first step is to counsel the shocked parents, as the birth of a baby with ambiguous genitalia is unexpected for both parents and the medical team. Parents need support and usually have many questions. The team leader should meet with them and provide initial information and support including offering the family the opportunity to have a supportive family member or a close friend to join them. Also, the role of the leader is to advise the parents to delay the registration of the birth, discuss with them the diagnosis, initial treatment plan, findings relevant to sex assignment, the team's recommendations and options, and to provide information and current evidence regarding gender identity outcomes in similar cases.

\section{History}

A complete detailed history from the parents is essential for an appropriate diagnosis $(5,8)$ including unexplained sudden infant death, ambiguity, infertility, precocious puberty, amenorrhea, hirsutism, maternal exposure to hormones (particularly progestagens and steroids), $(9,10)$ or consanguinity. The possibility of aromatase deficiency or maternal androgen secreting tumors with a history of maternal virilization during pregnancy should be considered $(5,11,12)$.

\section{Physical examination}

Parents should be informed in advance about the method of examination and it should be demonstrated to them. In a warm place, with the baby in the frog leg position, a general inspection is performed focusing on the genital anatomy $(5,8)$. After inspection, palpate for the gonads within the inguinal canal, scrotum, and labioscrotal folds, using the appropriate technique. The gonads are sometimes not palpable. A palpable gonad is most likely testis or rarely an ovotestis because a streak gonad and ovaries do not descend. Measure an abnormal phallic width and stretched length, examine for fused labia or biffed scrotum and determine the position of urethral opening and other orifices in the perineum. The Prader classification (Fig. 1) provides a useful guide to classify the DSD clinical approach 
from 1 (mild clitoromegaly) to 5 (complete virilization with urethral opening up at the tip of enlarged phallus) (13). The patient is classified according to the palpable or nonpalpable gonads
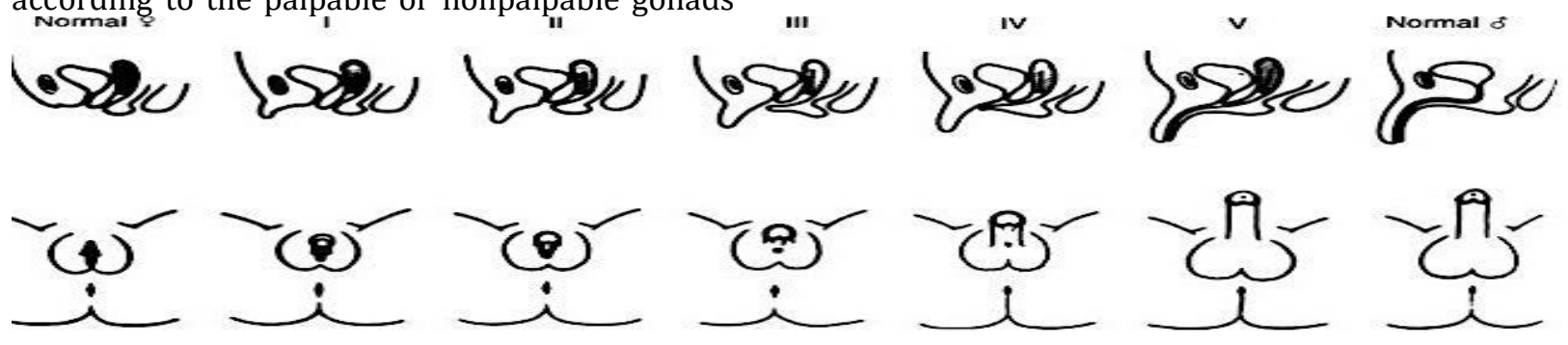

approach (Fig. 2) for differential diagnosis and investigation purposes.
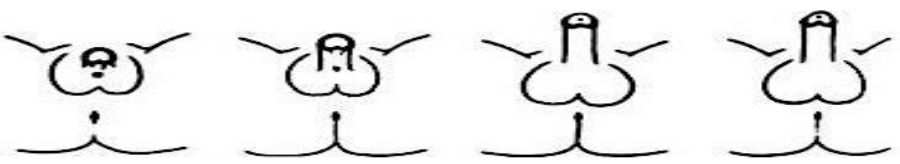

Fig.1.The degree of virilizatino of external genitalia of females as proposed by Prader. In Prader 1 the only abnormality is mild clitoromegaly with separate openings for urethra

and vagina. Praders 2 through 4 demonstrates the progression of virilization from mild to severe. Prader 5 is a markedly enlarged phallus with penile urethra.

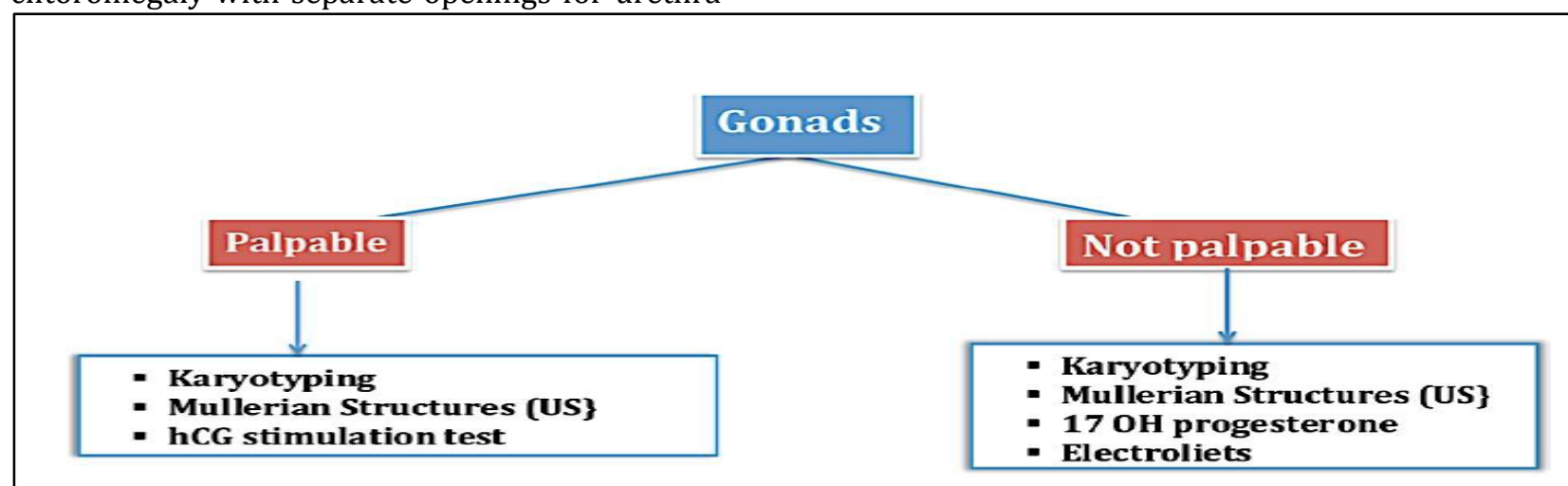

Fig.2.Algorithm for basic investigation for patient with DSD based on gonadal palpation. Abbreviations: DSD, disorder of sex development; hCG, human chorionic gonadotropin. Abbreviations: $\mathrm{CAH}$, congenital adrenal

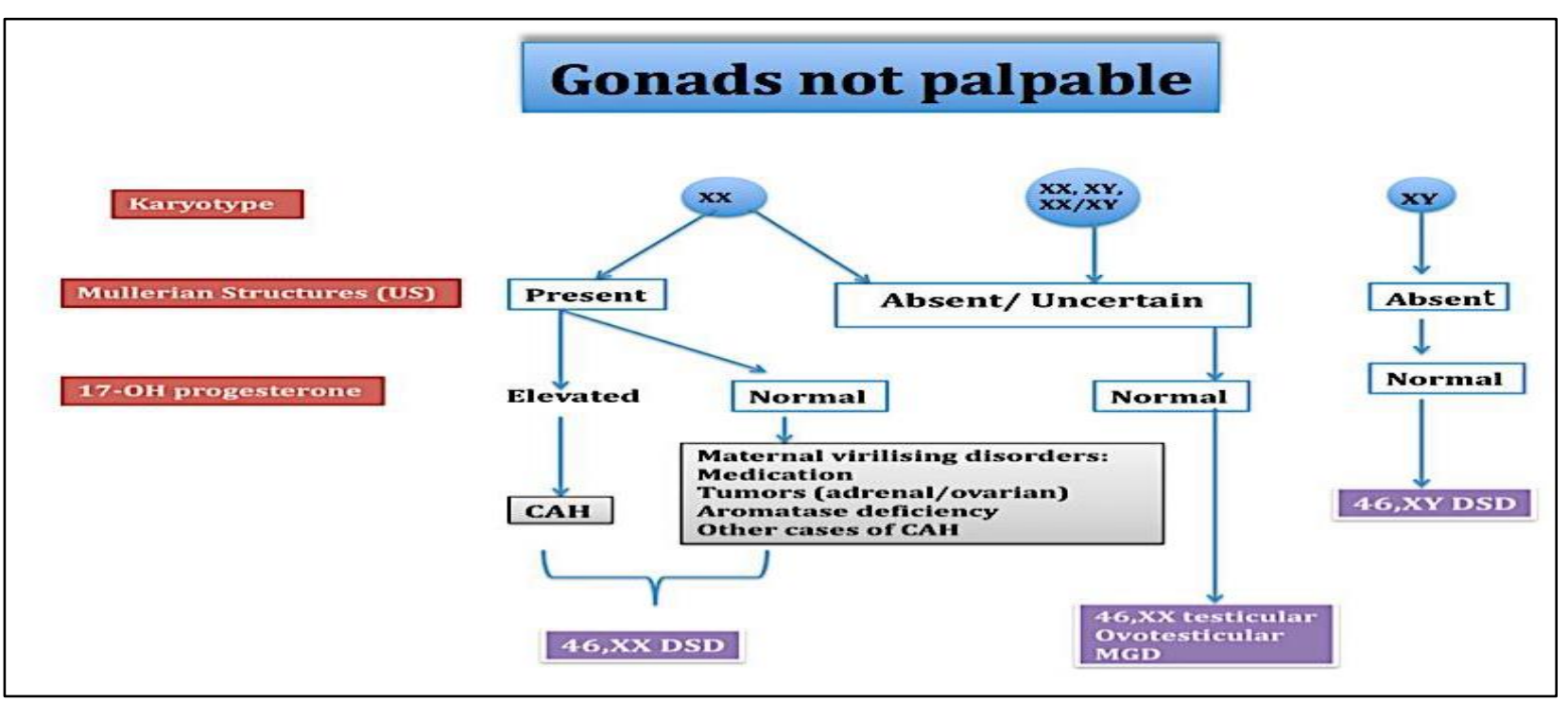


Fig.3. Algorithm for diagnosing DSD in patients with impalpable gonads by incorporating findings from karyotyping, imaging studies and other laboratory analyses. Abbreviations: $\mathrm{CAH}$, congenital adrenal hyperplasia; DSD, disorder of sex development; MGD, mixed gonadal dysgenesis.

\section{Basic Investigation}

The basic diagnostic tests for all patients are karyotyping and pelvic ultrasound to evaluate the presence of Mullerian structures. Other tests that should be done are, for example, the measurement of serum levels of sodium, potassium and 17hydroxyprogesterone (17-OHP) on the third day of life or later for patients with nonpalpable gonads. This is important because congenital adrenal hyperplasia (CAH), the most common DSD, may result in a life-threatening salt-losing crisis. In addition, a patient with palpable gonads should undergo a human chorionic gonadotropin (hCG) stimulation test to assess the gonadal production of androgens.

Possible diagnosis and further investigation depend on the results of the initial investigations (Fig. 3, 4).

\section{XX DSD (female pseudohermaphroditism)}

Patients in this category have a normal female karyotype and Mullerian structures but variable degrees of virilization of external genitalia with nonpalpable gonads. An elevated serum 17-OHP indicates the presence of $\mathrm{CAH}$, the frequent cause of $46 \mathrm{XX}$ DSD $(14,15,16,17,18)$ due to 21 -alpha hydroxylase-CYP21 deficiency, which leads to the accumulation of 17-OHP and excessive production of androgens (Fig. 5). Most patients have the saltwasting form, which can present with a lifethreatening adrenal crisis in the second or third week of life (19). If the levels of 17-0HP are normal, other types of CAH should be investigated. For example, an enzymatic defect in the adrenal cortisol synthesis pathway $11 \beta$-Hydroxysteroid $(11 \beta-0 H)$ or $3 \beta$-hydroxysteroid dehydrogenase ( $3 \beta-\mathrm{HSD})$, can lead to the excessive production of androgens and the accumulation of their precursors (Fig. 5). Other rare causes of 46XX DSD include medication, tumors (adrenal or ovarian) and aromatase deficiency. The identification of such causes can be accomplished through a complete history, physical examination and the demonstration of a high androgen level.

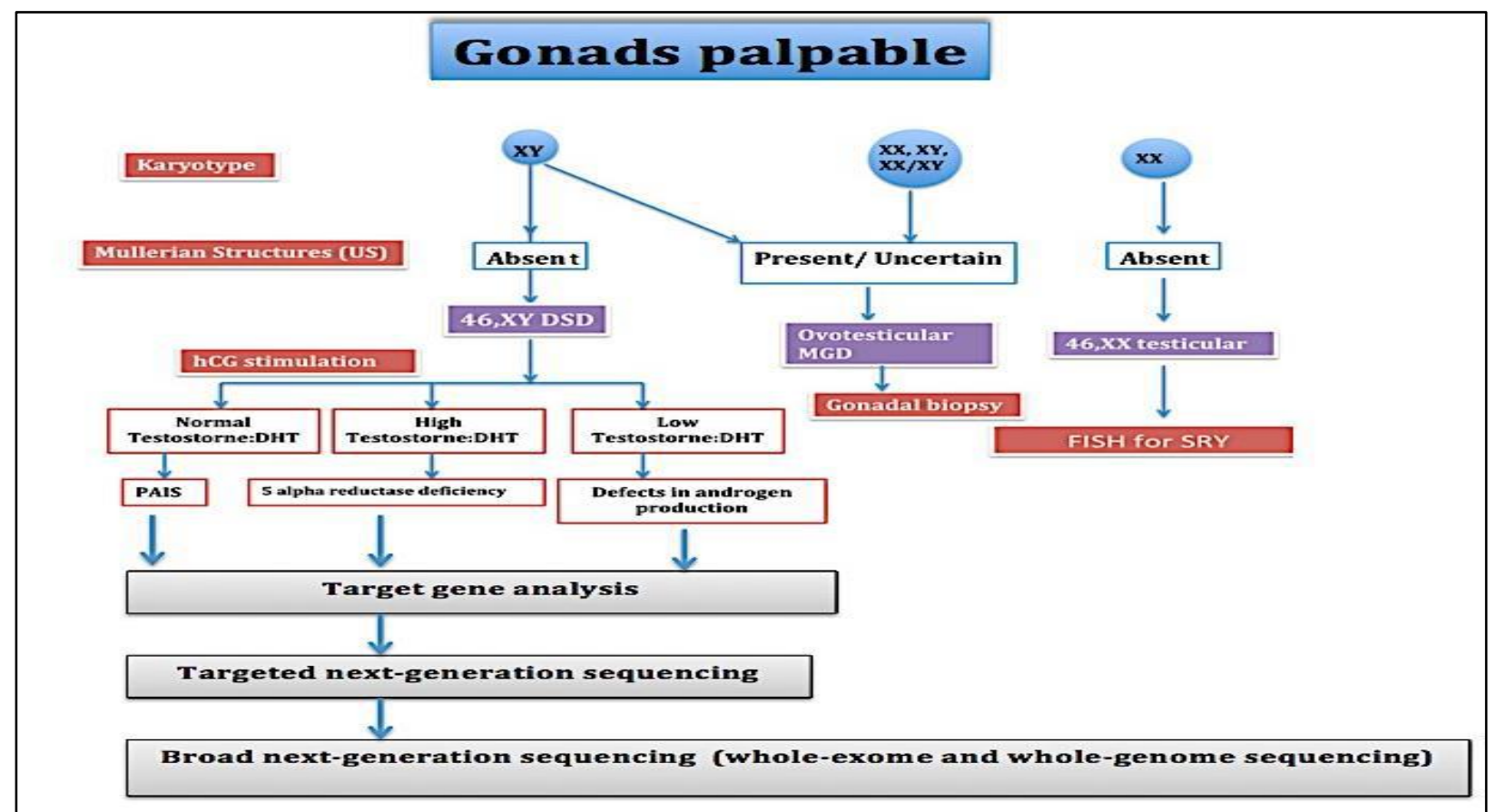

Fig.4.Algorithm for diagnosing DSD in patients with palpable gonads by incorporating findings from karyotyping, imaging studies and other laboratory analyses. Either targeted gene analysis or targeted next-generation sequencing is preferable for accurate diagnosis of known gene disorder before an untargeted analysis is performed. Abbreviations: DSD, disorder of sex development; MGD, mixed gonadal gysgenesis; FISH, fluorescent in situ hybridization; hCG, human chorionic gonadotropin; SRY, sex- 
determining region Y protein.

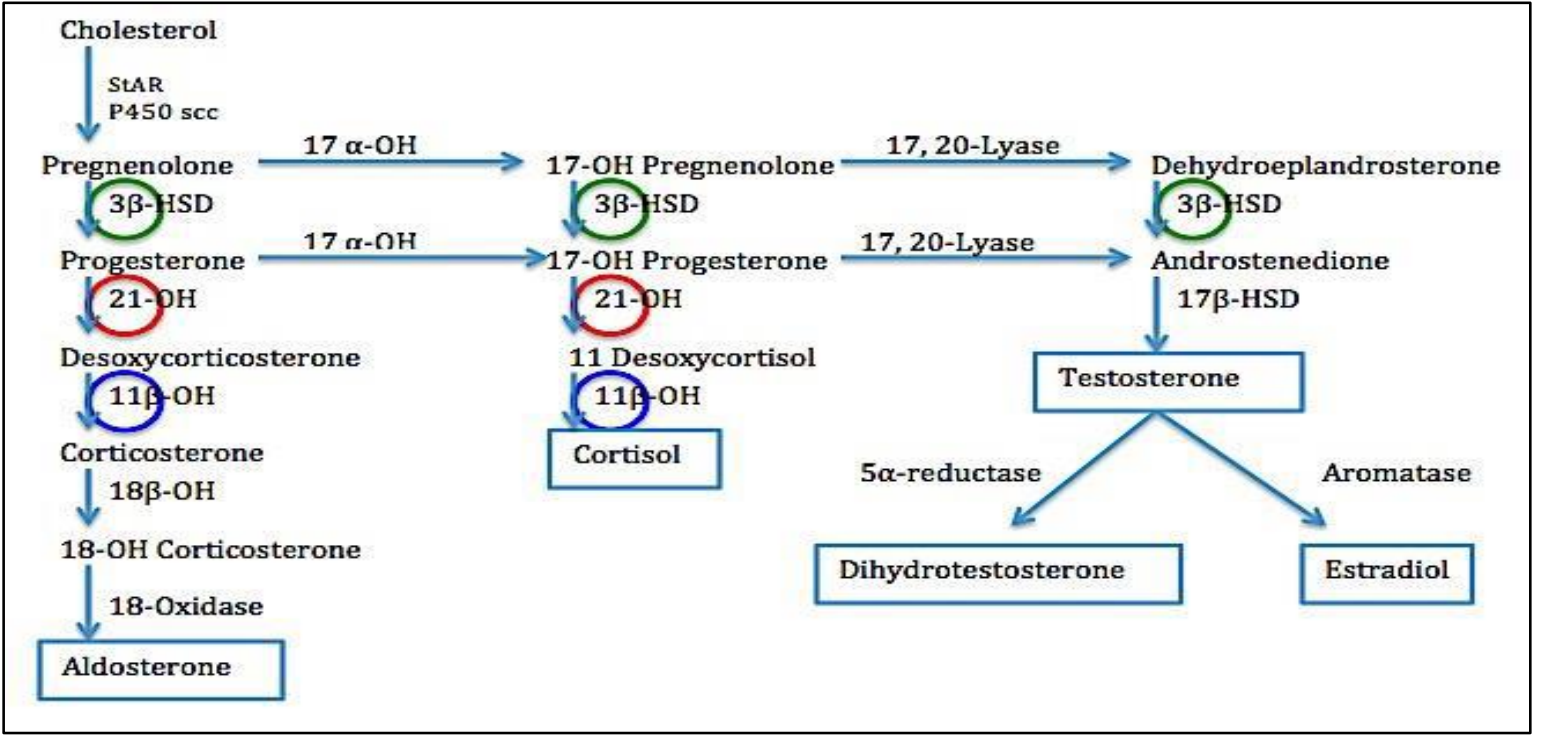

Fig. 5.The androgen pathway and the mechanism of virilization caused by the most Common form of $\mathrm{CAH}(21-\mathrm{OH}$ deficiency, $3 \beta-\mathrm{OSH}$ deficiency and $11 \beta-\mathrm{OH}$ deficiency). Note that accumulation of precursors above the enzymatic defect lead to virilization by excessive production of androgen.
Abbreviations: StAR, steroidogenic Acute Regulatory protein; $3 \beta$-HSD, 3 $\beta$-Hydroxysteroid; 21-OH, 21-hydroxylase; $\quad 11 \beta-\mathrm{OH}, \quad 11 \beta$ Hydroxysteroid dehydrogenase; $17 \beta-H S D, \quad 17 \beta-$ Hydroxysteroid dehydrogenase; $18 \beta-\mathrm{OH}, 8 \beta-$ hydroxylase.

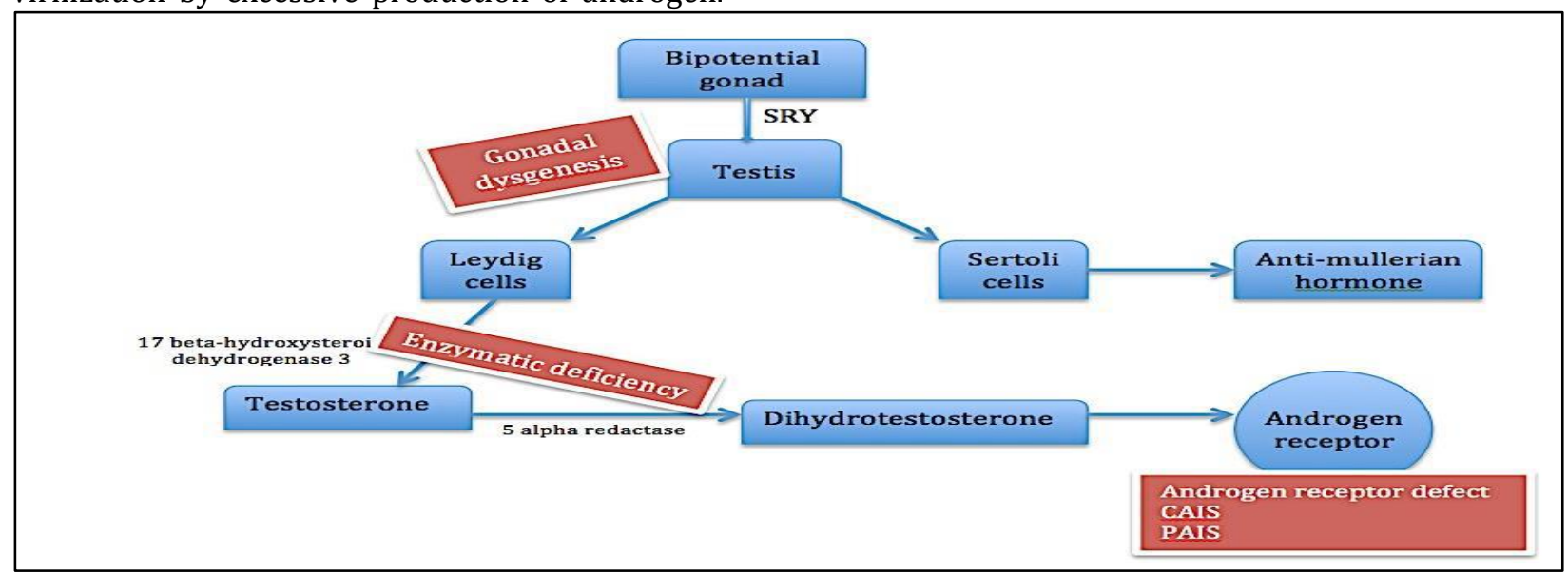

Fig. 6.Mechanism of virilization of the male external genitalia. Triangular shaped boxes demonstrate the main causes of undervirilization. Abbreviations: PAIS, partial androgen insensitivity syndrome; CAIS, complete l androgen insensitivity syndrome

\section{XY DSD (male pseudohermaphroditism)}

Patients in this category have a normal male karyotype and absence of Mullerian structures but with variable degrees of undervirilization of external genitalia with palpable gonads in most of cases. Fig. 6.Illustrates the mechanism of virilization of the male external genitalia and the main causes of undervirilization. An hCG stimulation test is a reliable test to determine the gonadal function and it assists in diagnosing the most common causes of 46XY DSD [partial androgen insensitivity syndrome (PAIS) and 5alpha reductase deficiency (5-ARD)]. In PAIS, testosterone (T) and dihydrotestosterone (DHT) levels are high while in 5-ARD, the ratio of $\mathrm{T}$ to DHT is high, unresponsive testosterone indicates gonadal failure due to either structural or hormonal synthesis defects and elevated 
testosterone precursors may indicate a defect of testicular testosterone synthesis (Fig. 6). There is no consensus about the way how an hCG stimulation test should be conducted, but the protocol we used is daily intramuscular hCG 1000-1500 units for three consecutive days, and measuring basal serum dehydroeplandrosteronesulfate, androstenedione, $\mathrm{T}$ and DHT 24 hours after the last injection (20). Another protocol, twice-weekly injections for 3 weeks, can also be used but it takes much longer. In case of normal hCG results, an adrenocorticotropic hormone (ACTH) stimulation

\section{Ovotesticular disorder of sexual development (true hermaphroditism)}

It is a rare disorder of sexual differentiation with geographic variations in the incidence and karyotyping (21). It constitutes about $3-10 \%$ of all $\operatorname{DSD}(6,22,23)$. However, in Southern Africa, this condition occurs in $51 \%$ of DSD patients (21). It is characterized by the presence of gonads of ovotestis or a combination of testis on one side and an ovary or ovotestis on the other side. The main clinical presentation is ambiguous genitalia and a unilateral palpable gonad, which can be either be an ovotestis or testis, usually located in the right side $(24,25,26)$. Karyotyping is variable. $46 \mathrm{XX}$ is the most frequent and constitutes about $60 \%$ of cases (27-30), followed by mosaicism $46 X X / 46 X Y \quad(25-30 \%)$ and 46XY (10-15\%) $(30,31)$. Internal sex duct development usually corresponds with the adjacent gonad. Wolffian duct structures typically develop on the gonadal side that contain testicular tissue whereas Müllerian duct structures tend to be observed on the gonadal side that do not contain testicular tissue (32). The patients with ovotesticular DSD could be found in both the palpable and nonpalpable gonads groups (Fig.3, 4) but 46XX DSD with a palpable gonad should raise a strong suspicion of ovotesticular DSD. An uncertain Müllerian duct structure is identified with ultrasound and the androgen concentration could be normal for the male range if testicular tissue is predominant. A diagnosis of ovotesticular DSD is dependent solely on the gonadal biopsy results, which should show the presence of ovarian follicles and testicular seminiferous tubules (27).

\section{XX testicular DSD}

It is a rare disorder with an estimated prevalence of $1 / 20,000$ males. The nomenclature indicates that patients with $46 \mathrm{XX}$ testicular DSD have a test demonstrates a specific defect in adrenal testosterone syntheses such as $17 \alpha$-hydroxylase and 17,20-lyase. An objective of the rapid advances in genetic studies for DSD in recent years was to make a definitive diagnosis and provide genetic counseling for families. The 46XY DSD mutation, in particular, has been identified in the androgen receptors in about $50 \%$ of PAIS and in the 5-alpha reductase gene (SRD5A2). Although genetic testing is an excellent tool that can aid in the diagnosis, it is expensive, not widely available and cannot replace the clinical approach.

46XX karyotype and testes. The appearance of external genitalia depends on the presence of the SRY-gene. Approximately $80-90 \%$ of patients is SRY-gene positive (33) and has normal male external genitalia. They usually present with infertility, delayed puberty, gynecomastia and a short stature (34). Endocrine tests show hypergonadotropichypogonadism due to testicular failure $(35,32)$. On the other hand, patients who are SRY-gene negative (10-20\%), usually have ambiguous genitalia presenting at birth or infancy $(36,37)$. Clinically patients will be

in the palpable gonads group (Fig.3). Patients with 46 XX karyotype and absent normal female internal ducts should raise the suspicion of $46 \mathrm{XX}$ testicular DSD diagnosis, which could be confirmed by identifying the SRY-gene using fluorescence in situ hybridization (FISH) or chromosomal microarray (CMA).

46XY complete gonadal dysgenesis (CGD) Patients with 46XY CGD are phenotypically females; they have normal female internal ducts (fallopian tubes, uterus and vagina) and external female genitalia. The patient cannot be identified at birth or childhood and is only diagnosed in adolescence or adulthood when they present with primary amenorrhea, delayed puberty but with a normal stature and the absence of dysmorphic features. This disorder is also referred to as Swyer syndrome, named after Swyer and colleagueswho initially described the female appearance of a patient with negative X-chromatin, normal stature and having streak gonads (38). The majority of cases of XY CGD are of unknown etiology; SRY mutations and deletions have been identified in about $10-20 \%$ of the cases $(39,40)$. Other deletions that were described include NR5A1 
(9q33) (41, 42, 1), CBX2 (17q25) (54), DMRT1 (9p24.3) $(43,44)$, and a heterozygous mutation in MAP3K1 (5q11.2) (45). Patients at pubertal age have high levels of follicle-stimulating hormone (FSH), luteinizing hormone (LH) and low estrogens, which indicate gonadal failure. FISH for SRY and comparative genomic hybridization (CGH) are recommended to identify the etiology (43). The treatment consists of hormone replacement therapy and surgical removal of any streak gonads, if present, because of the high potential for malignancy (gonadoblastoma or dysgerminoma) 20-30\% $(46,47)$.

\section{Sex assignment}

At birth or infancy sex assignment depends on the following factors: 1) Potential for sexual activity. 2) Potential for fertility. 3) The feasibility of constructive surgery. 4) The type of DSD. 5) Prenatal androgen exposure. 6) Family culture $(19,48)$. For $46 \mathrm{XX} \mathrm{CAH}$, the most frequent condition of DSD, the consensus is to raise individuals as female because $90 \%$ of patients have a female gender identity, however, about 5\% of patients have gender dysphoria (49). Most patients with $46 \mathrm{XX} \mathrm{CAH}$ have the potential for normal sexual function and fertility. However, some publications recommend male gender assignment for markedly virilized patients (Prader 5 and some Prader 4) (13). The topic is controversial, but currently, the recommendation is to raise all patients with $46 \mathrm{XX} \mathrm{CAH}$ as females whatever the stage of virilization (23). The recommendation for patients with 46XY complete androgen insensitivity (CAIS) or complete gonadal dysgenesis is to be raised as females as they are accepting themselves as female, have not been exposed in utero to an effective androgen that may affect their identity $[48,50]$, are phenotypically females and have an adjusted sexual life. However, some of these individuals have been reported as having a male gender identity. Patients with $46 \mathrm{XY} 5 \alpha$ reductase or $17 \beta$ hydroxysteroid dehydrogenase3 deficiency are usually recommended to be raised as males even with severe undervirilization (51). The recommendations reflect the potential for virilization at puberty (33) and the possibility for fertility $(52,53)$ and are supported by literature, reporting that more than $60 \%$ of $5 \alpha$-reductasedeficient patients and $50 \%$ of $17 \beta$-hydroxysteroid dehydrogenase-3 deficiency patients, who are assigned as female in infancy, ultimately change their gender role (54). However, there are some case reports about patients with $17 \beta$ hydroxysteroid dehydrogenase-3 deficiency that were assigned females (41). For patients with incomplete gonadal dysgenesis, PAIS and androgen biosynthetic defects, there is still no consensus or recommendations regarding sex assignment, about $25 \%$ of individuals are dissatisfied with the sex of rearing whether they are raised as a boy or a girl (55). The decision of sex assignment in patients with ovotesticular DSD depends on the degree of gonadal function and its effect on genital development, the possibility of fertility and normal sexual activity. The same should be considering for patients with mixed gonadal dysgenesis (MGD). Individuals with cloacalexstrophy are usually raised as females $(65 \%)$ but there is variability in gender identity outcomes (19).

\section{Surgical management}

The time for repair with feminizing genitoplasty, which include clitoroplasty, labioplasty and vaginoplasty is not well defined; most surgeons prefer early surgery in infancy and in a specialized center for patients with significant virilization (Prader 3 or higher) $(19,56,7)$. Studies reported that early surgery may improve the relationship between children and their parents and relieve parental distress (57-59). It also assists in avoiding complications from the connection between the peritoneum and the urinary tract and benefits from the estrogen effect on tissue in early infancy (56). Several surveys demonstrated that surgery early in life for patients with CAH does not affect their physical and mental quality of life more than other surgical and nonsurgical chronic medical conditions $(60,61)$. Most women with $\mathrm{CAH}$ favor surgery before adolescence $(21,22)$ although some studies show poor functional and cosmetic results of genitoplasty done in infancy $(59,60)$ with a high rate of re-intervention in adulthood (62). Other surgeons prefer deferring at least vaginoplasty until puberty, as most of the patients require vaginal dilatation at that time (63-65) if the surgery is done early. The evidence for either approach is limited. Vaginal dilatation should be avoided before puberty. There is no systematic evidence for prophylactic removal of asymptomatic discordant structures, such as a Mullerian remnants or utriculus. The testes should be removed at the time of diagnosis for patients with CAIS (26), PAIS raised female and androgen biosynthetic defects raised female to prevent malignancy in adulthood, associated hernia and psychological problems with the presence of testes. The streak gonads are also at risk of 
malignancy and the current recommendations are that they have to be removed in early childhood for patients with MGD raised male (66) and females with gonadal dysgenesis and $Y$ chromosome (64). A scrotal testis is at increased risk for developing into a malignancy in patients with gonadal dysgenesis and testicular biopsy is recommended at puberty for early diagnosis of premalignant lesion (67). In patients with bilateral ovotestes, separation of ovarian and testicular tissue is performed early in life, as patients are potentially fertile from functional ovarian tissue $(66,68)$.

\section{Genetics}

In the near future, genetic diagnosis of DSD will become the primary and most accurate approach for diagnosis. The rapid progression of genetic techniques enables diagnosis of complex diseases such as DSD through next-generation sequencing (NGS), which includes: 1)

chromosomal microarray, which allows the detection of copy number variants (CNVs) microduplications and microdeletions as small as $50 \mathrm{~kb}(69,70)$. In two studies examining a large number of patients with DSD (116 and 23, respectively), CNVs were identified in $13 \%$ to $21.5 \%$ of the cases $(71,72) .2)$ Coding regions of the genome (whole-exome sequencing) represent $1 \%-2 \%$ of the entire genome, but contain around $85 \%$ of the mutations that cause known genetic disorders $(73,74)$ and identify significant variants in novel DSD genes (75). 3) Targeted gene sequencing (TGS) is an accurate and fast way to diagnose DSD if the causative gene is known. The coding sequences of 35 known genes involved in sex determination have been developed (76). The best example of advanced progress in genetic diagnosis of DSD is the ability to diagnose the fetal CAH as early as 5 weeks 6 days of gestation by targeted massively parallel sequencing (MPS) of DNA in maternal plasma (77).

\section{Risk of gonadal malignancy}

Patients with DSD are at increased risk for gonadal malignancies especially germ cell tumors such as dysgerminomas, seminomas and nonseminomas. The risk in general depends on: 1) the presence of a Y chromosome with undervirilization particularly gonadal dysgenesis and ovotestis (78). 2) The location of the gonad(s). The risk of malignancy is $20 \%-30 \%$ for patients with complete gonadal dysgenesis and 15\%-20\% for those with mixed gonadal dysgenesis $(45,79)$. Gonadoblastomas are the most common gonadal tumors and they develop within the first to second decade of life and a gonadectomy is the current management (80). Abdominal or pelvic testis is also at increased risk of tumor development and should be either removed in patients raised as females or descended into the scrotum if raised as males. The scrotal testis is at risk of malignancy in patients with gonadal dysgenesis, and a biopsy is required at the time of puberty to diagnose the tumor early (81). Patients with ovotestis or CAIS have the lowest risk $(0.5 \%)$ of developing malignancies $(40,48)$.

\section{Conclusion}

Much progress has been made in the knowledge and diagnosis of individuals with DSD. DSD conditions are complex and need a multidisciplinary team with knowledgeable and skillful experts in the management of DSD and specialized centers with the best facilities for diagnosis and management. Parents and patients should be informed in detail about each step in the management and should be informed about the diagnosis and enough time to answer any inquiry. A clinical algorithm facilitates making the final diagnosis and avoids unnecessary investigation and reserve resources. The goal of DSD management in infancy should be to maintain stable gender identity, preserve potential sexual function and fertility and provide cosmetic and functioning external genitalia. Management includes different but important components such as diagnosis, family support, sex assignment and the risk of malignancy. Each component needs accuracy and cautious decision-making. Future studies are essential to be able to determine the cause and the most appropriate management for each individual patient.

\section{Declaration of interest}

The authors declare that they have no conflict of interest.

\section{Funding}

This research did not receive any specific grant from any funding agency in the public, commercial or not-for-profit sector.

\section{References}


1. Mukherjee AB, Parsa NZ. Determination of sex chromosomal constitution and chromosomal origin of drumsticks, drumstick-like and other nuclear bodies in human blood cells at interphase by fluorescence in situ hybridization. Chromosoma 99: C432-C435, 1990.

2. Rey R, Josso N, Racine C. Sexual Differentiation. [Updated 2016 Jun 12]. In: De Groot LJ, Chrousos, Dungan K, Feingold KR, Grossman A, Hershman JM, Koch C, Korbonits M, McLachlan R, New M, Purnell J, Rebar R, Singer F,Vinik A, editors. Endotext [Internet]. South Dartmouth (MA): MDText.com, Inc;; 2000-.2016 Jun 12.

3. Fauci AS, Barunwald E, Kasper D, Hauser S, Longo D, Jameson JL, Loscalzo J. Harrison's principles of internal medicine (17th ed.). New York: McGraw-Hill Medical. 2339-2346, 2008.

4. Hughes IA. Minireview: Sex Differentiation. Endocrinology 142: C3281-3287, 2001.

5. Lee PA, Houk CP, Ahmed SF, Hughes IA, International Consensus Conference on Intersex organized by the Lawson Wilkins Pediatric Endocrine Society and the European Society for Paediatric Endocrinology: Consensus Statement on Management of Intersex Disorders. International Consensus Conference on Intersex. Pediatrics 118:E488-E500, 2006.

6. Hughes IA, Houk C, Ahmed SF, Lee PA. Lawson Wilkins Pediatric Endocrine Society/European Society for Paediatric Endocrinology Consensus Group. Consensus statement on management of intersex disorders. J Pediatr Urol. 2: C148-C162, 2006.

7. Schaeffer TL, Tryggestad JB, Mallappa A, Hanna AE, Krishnan S, Chernausek SD, Chalmers LJ, Reiner WG, Kropp BP, Wisniewski AB. An evidence-based model of multidisciplinary care for patients and families affected by classical congenital adrenal hyperplasia due to 21-Hydroxylase Deficiency. Int J PediatrEndocrinol2010: C692439, 2010.

8. Clayton PE, Miller WL, Oberfield SE, Ritzén EM, Sippell WG, Speiser PW, ESPE/LWPES CAH Working Group. Consensus statement on 21-hydroxylase deficiency from the European Society for Paediatric Endocrinology and the Lawson Wilkins Pediatric Endocrine Society. Horm Res 58: C188-C195, 2002.

9. Cohen-Bendahan CC, van de Beek C, Berenbaum SA. Prenatal sex hormone effects on child and adult sextyped behavior: methods and findings. NeurosciBiobehav Rev 29: C353-C384, 2005.

10. Wallen K. Nature needs nurture: the interaction of hormonal and social influences on the development of behavioral sex differences in rhesus monkeys. HormBehav 30: C364-C378, 1996.

11. Ahmed SF, Rodie M. Investigation and initial management of ambiguous genitalia. Best Pract Res ClinEndocrinolMetab 24: C197-C218, 2010.

12. Spitzer RF, Wherrett D, Chitayat D, Colgan T, Dodge JE, Salle JL, Allen L. Maternal luteoma of pregnancy presenting with virilization of the female infant. J ObstetGynaecol Can 29: C835-C840, 2007.

13. Prader A. Der genitalbefundbeimppseudohermaphroditismusfemini nus der kengenitalenadrenogenitalensyndroms. HelvPaediatrActa 9: C231-C248,1954.

14. Hughes IA. Disorders of sex development: a new definition and classification. Best Pract Res ClinEndocrinolMetab 22: C119-C134, 2008.
15. Parisi MA, Ramsdell LA, Burns MW, et al. A gender assessment team: experience with 250 patients over a period of 25 years. Genet Med 9: C348-C357, 2007

16. Göllü G,Yildiz RV, Bingol-Kologlu M, Yagmurlu A, Senyücel MF, Aktug T, Gökcora IH, Dindar H.Ambiguous genitalia: an overview of 17 years' experience. J PediatrSurg 42: 840-844, 2007.

17. Ocal G, Berbero_glu M, Siklar Z, Bilir P, Uslu R, Yağmurlu A, Tükün A, Akar N, Soygür T, Gültan S, Gedik VT. Disorders of sexual development: an overview of 18 years experience in the pediatric endocrinology department of Ankara University. J PediatrEndocrinolMetab 23: C1123-C1132, 2010.

18. Meyer-Bahlburg HF. Gender and sexuality in classic congenital adrenal hyperplasia. EndocrinolMetabClin North Am 30:155-71, 2001.

19. Speiser PW, Azziz R, Baskin LS, Ghizzoni L, Hensle TW, Merke DP, Meyer-Bahlburg HF, Miller WL, Montori VM, Oberfield SE, Ritzen M, White PC; Endocrine Society. Congenital adrenal hyperplasia due to steroid 21-hydroxylase deficiency: an Endocrine Society clinical practice guideline. J ClinEndocrinolMetab 95: C4133-C4160, 2010.

20. Ahmed, S.F., Achermann, J.C., Arlt, W. et al. UK guidance on the initial evaluation of an infant or an adolescent with a suspected disorder of sex development. Clinical Endocrinology, 75, 12-26, 2011.

21. Ozsu E, Mutlu GY, Cizmecioglu FM, Ekingen G, Muezzinoglu B, Hatun S. Ovotesticular disorder of sexual development and a rare 46, XX/47, XXY karyotype. J PediatrEndocrinolMetab 26: C789-C791, 2013.

22. Wettasinghe KT, Sirisena ND, Andraweera $\mathrm{PH}$, Jayasekara RW, Dissanayake VH. A case series of five Sri Lankan patients with ovotesticular disorder of sex development. ClinPediatrEndocrinol 21: C69- C73, 2012.

23. Wiersma R, Ramdial PK. The gonads of 111 South African patients with OvoTesticular Disorder of Sex Differentiation.JPediatrSurg 44: C556-C560, 2011.

24. Luy SC, Ho F. A rare case of true hermaphrodite with features of Klinefelter syndrome. Philipp J Intern Med 51: 1-9, 2013.

25. Sircili MH, Denes FT, Costa EM, Machado MG, Inacio M, Silva RB, Srougi M, Mendonca BB, Domenice S. Longterm followup of a large cohort of patients with ovotesticular disorder of sex development. J Urol 191: C1532-C1536, 2013.

26. Van Niekerk WA, Retief AE. The gonads of human true hermaphrodites. Hum. Genet 58: C117-C122, 1981.

27. Krob G, Braun A, Kuhnle U. True hermaphroditism: geographical distribution, clinical findings, chromosomes and gonadal histology. Eur J Pediatr 153: C2-C10, 1994.

28. Walker AM, Walker JL, Adams S, Shi E, McGlynn M, Verge CF. True hermaphroditism. J Paediatr Child Health 36: C69-C73, 2000.

29. Achermann JC, Hughes IA. Disorders of sex development. In: William's Textbook of Endocrinology, 12th edn. Melmed S, Polonsky KS, Larsen PR, Kronenberg HM (eds). Saunders, Philadelphia, pp 887891, (2012).

30. Matsui F, Shimada K, Matsumoto F, Itesako T, Nara K, Ida S, Nakayama M. Long-term outcome of 
ovotesticular disorder of sex development: a single center experience. Int J Urol 18: 231-236, 2011.

31. Sperling MA. Pediatric endocrinology. Philadelphia: Saunders, 2008, p. 138.

32. McElreavey K, Vilain E, Abbas N, Herskowitz I, Fellous $M$. A regulatory cascade hypothesis for mammalian sex determination: SRY represses a negative regulator of male development. ProcNatlAcadSci U S A 90: 33683372, 1993.

33. De la Chapelle A. Analytic review: nature and origin of males with XX sex chromosomes. Am J Hum Genet 24: C71-C105, 1972.

34. Pérez-Palacios G, Medina M, Ullao-Aguirre A, Chávez BA, Villareal G, Dutrem MT, Cahill LT, Wachtel S. Gonadotropin dynamics in $\mathrm{XX}$ males. J ClinEndocrinolMetab 53: C254-C257, 1981.

35. Zenteno-Ruiz JC, Kofman-Alfaro S, Méndez JP. 46,XX sex reversal. Arch Med Res 32: C559-C566.2001.

36. Grigorescu-Sido A, Heinrich U, Grigorescu-Sido P, Jauch A, Hager HD, Vogt PH, Duncea I, Bettendorf M. Three new 46,XX male patients: a clinical, cytogenetic and molecular analysis. J PediatrEndocrinolMetab. 18: C197-C203, 2005.

37. Swyer GI:. Male pseudohermaphroditism: a hitherto undescribed form. Brittish Medical Journal 2: C709C712, 1995.

38. Michala L, Creighton SM. The XY female. Best Prac Res ClinObstetGynaecol 24: 139-148, 2010.

39. Rocha VB, Guerra-Junior G, Marques-de-Faria AP. Complete gonadal dysgenesis in clinical practice: the 46,XY karyotype accounts for more than one third of cases. FertilSteril 96: C1431-C1434, 2011.

40. Cools M, Van Aerde K, Kersemaekers AM, Boter M, Drop SL, Wolffenbuttel KP, Steyerberg EW, Oosterhuis JW, Looijenga LH. Morphological and immunohistochemical differences between gonadal maturation delay and early germ cell neoplasia in patients with undervirilization syndromes. J ClinEndocrinolMetab 90: C5295-C5303, 2005.

41. Migeon CJ, Wisniewski AB, Gearhart JP, MeyerBahlburg HF, Rock JA, Brown TR, Casella SJ, Maret A, Ngai KM, Money J, Berkovitz GD. Ambiguous genitalia with perineoscrotal hypospadias in 46,XY individuals: long-term medical, surgical, and psychosexual outcome. Pediatrics 110: Ce31, 2002.

42. Moore CL. The role of maternal stimulation in the development of sexual behavior and its neural basis. Ann N Y AcadSci 662: 160-77, 1992.

43. Muroya K, Okuyama T, Goishi K. Sex-determining gene(s) on distal 9p: clinical and molecular studies in six cases. J ClinEndocrinolMetab 2000 85: 3094-3100, 2000.

44. Pearlman A, Loke J, Le Caignec C. Mutations in MAP3K1 cause 46,XY disorders of sex development and implicate a common signal transduction pathway in human testis determination. Am J Hum Genet 87: C898-C899, 2010.

45. Looijenga LHJ, Hersmus R, Oosterhuis JW, Cools M, Drop SL, Wolffenbuttel KP. Tumor risk in disorders of sex development (DSD). Best Pract Res ClinEndocrinolMetab 21: 480-495, 2007.

46. Simpson JL, Photopulos G. The relationship of neoplasia to disorders of abnormal sexual differentiation. Birth Defects Orig Artic Ser 12: C15-
C50, 1976.

47. Byne W. Developmental endocrine influences on gender identity: implications for management of disorders of sex development. MtSinai J Med 73: C950C959.

48. Dessens AB, Slijper FM, Drop SL. Gender dysphoria and gender change in chromosomal females with congenital adrenal hyperplasia. Arch Sex Behav 34: C389-C397, 2005.

49. Houk CP, Lee PA. Approach to assigning gender in 46, $\mathrm{XX}$ congenital adrenal hyperplasia with male external genitalia: replacing dogmatism with pragmatism. J ClinEndocrinolMetab 95: C4501-C4508, 2010.

50. Bertelloni S, Balsamo A, Giordani R, Fischetto R, Russo M, Delvecchio M, Genarri M, Nicoletti A, Maggio MC, Concolino D, Cavallo L, Cicognani A, Chiumello G, Hiort O, Baroncelli GI, Faienza MF. 17 $\beta$-Hydroxysteroid dehydrogenase-3 deficiency: from pregnancy to adolescence. J Endocrinol Invest 32: 666-670, 2009.

51. Werner R, Kulle A, Sommerfeld I, Riepe FG, Wudy S, Hartman MF, Merz H, Döhnert U, Bertelloni $\mathrm{S}$, Holterhus PM, Hiort 0 . Testosterone synthesis in patients with $17 \beta$-hydroxysteroid dehydrogenase 3 deficiency. Sex Dev 6: C161-C168, 2012.

52. Kang HJ, Imperato-McGinley J, Zhu YS, Rosenwaks Z. The effect of $5 \alpha$-reductase- 2 deficiency on human fertility. FertilSteril 101: 310-316, 2014.

53. Cohen-Kettenis PT. Gender change in 46,XY persons with 5-alpha-reductase-2 deficiency and 17-betahydroxysteroid dehydrogenase-3 deficiency. Arch Sex Behav34: C399- C410, 2005.

54. M, Hampel E, Hiort $\mathrm{O}$, Thyen U. "Any decision is better than none" decision-making about sex of rearing for siblings with 17 $\beta$-hydroxysteroid-dehydrogenase-3 deficiency. Arch Sex Behav 35: C359-C371, 2006.

55. -Bahlburg HF. Gender identity outcome in femaleraised 46,XY persons with penile agenesis, cloacalexstrophy of the bladder, or penile ablation. Arch Sex Behav 34: 423-438, 2005.

56. Warne G, Grover S, Hutson J, Sinclair A, Metcalfe S, Northam E Freeman J; Murdoch Childrens Research Institute Sex Study Group. A long-term outcome study of intersex conditions. J PediatrEndocrinol Met 18: C555-C567, 2005.

57. Farkas A, Chertin B, Hadas-Halpren I. 1-Stage feminizing genitoplasty: 8 years of experience with 49 cases. J Urol 165: C2341-2346, 2001.

58. Crouch NS, Minto CL, Laio LM, Wooshouse CR, Creighton SM. Genital sensation after feminizing genitoplasty for congenital adrenal hyperplasia: a pilot study. BJU Int 93: C135-C138, 2004.

59. American Academy of Pediatrics. Timing of elective surgery on the genitalia of male children with particular reference to the risks, benefits, and psychological effects of surgery and anesthesia.Pediatrics 97: C590-C594, 1996.

60. Stikkelbroeck NM, Beerendonk CC, Willemsen WNP, Schreuders-Bais CA, Feitz WF, Rieu PN, Hermus AR, Otten BJ. The long-term outcome of feminizing genital surgery for congenital adrenal hyperplasia: anatomical, functional and cosmetic outcomes, psychosexual development, and satisfaction in adult female patients. J PediatrAdolescGynecol 16: C289C296, 2003. 
61. Creighton SM, Minto CL, Steele SJ. Objective cosmetic and anatomical outcomes at adolescence of feminising surgery for ambiguous genitalia done in childhood. Lancet 358: 124-125, 2001.

62. Eroglu E, Tekant G, Gundogdu G, Emir H, Ercan O, Söylet Y, Danişmend N. Feminizing surgical management of intersex patients. PediatrSurgInt 20: C543-C547, 2004.

63. Alizai NK, Thomas DF, Lilford RJ, Batchelor AG, Johnson N. Feminizing genitoplasty for congenital adrenal hyperplasia: what happens at puberty? J Urol 161: C1588-C1591, 1999.

64. MM, Gearhart JP, Migeon C, Rock J. Vaginal reconstruction after initial construction of the external genitalia in girls with salt wasting adrenal hyperplasia. J Urol 148: C680-C684, 1992.

65. Williams RH, Larsen PR. Disorders of sex differentiation. In: Williams textbook of endocrinology, edited by P. Reed Larsen. Philadelphia: WB Saunders, 2003, p. 842-1002.

66. Rangecroft L. Surgical management of ambiguous genitalia. Arch Dis Child 88: C799-C801, 2003.

67. Nihoul-Fe'ke'te' C. The Isabel Forshall Lecture. Surgical management of the intersex patient: an overview in 2003. J PediatrSurg 39: C144-C145, 2004

68. Ostrer $H$. Changing the game with whole exome sequencing. Clin Genet. 80: C101-C103, 2011.

69. Wheeler DA, Srinivasan M, Egholm M, Shen Y, Chen L, McGuire A, He W, Chen YJ, Makhijani V, Roth GT, Gomes X, Tartaro K, Niazi F, Turcotte CL, Irzyk GP, Lupski JR, Chinault C, Song XZ, Liu Y, Yuan Y, Nazareth L, Qin X, Muzny DM, Margulies M, Weinstock GM, Gibbs RA, Rothberg JM. The complete genome of an individual by massively parallel DNA sequencing. Nature 452: C872-C876, 2008.

70. Tannour-Louet $\mathrm{M}$, Han S, Corbett ST, Louet JF, Yatsenko S, Meyers L, Shaw CA, Kang SH, Cheung SW, Lamb DJ. Identification of de novo copy number variants associated with human disorders of sexual development. PLoS One 5: e15392, 2010.

71. S, Ohnesorg T, Notini A, Roeszler K, Hewitt J, Daggag H, Smith C, Turbitt E, Gustin S, van den Bergen J, Miles D, Western P, Arboleda V, Schumacher V, Gordon L, Bell K, Bengtsson H, Speed T, Hutson J, Warne G, Harley V, Koopman P, Vilain E, Sinclair A. Copy number variation in patients with disorders of sex development due to 46, XY gonadal dysgenesis. PLoSOne 6: Ce17793, 2011.

72. SB, Buckingham KJ, Lee C, Bigham AW, Tabor HK, Dent KM, Huff CD, Shannon PT, Jabs EW, Nickerson DA, Shendure J, Bamshad MJ.Exomesequencing identifies the cause of a mendelian disorder. Nat Genet 42: C30-C35, 2010.

73. Shendure J, Porreca GJ, Reppas NB, Lin X, McCutcheon JP, Rosenbaum AM, Wang MD, Zhang K, Mitra RD, Church GM. Accurate multiplex polony sequencing of an evolved bacterial genome. Science 309: C1728C1732, 2005.

74. Cooper DN, Krawczak M. The mutational spectrum of single basepair substitutions causing human genetic disease: patterns and predictions. Hum Genet 85: C55C74, 1990.

75. Arboleda VA, Lee H, Sánchez FJ, Délot EC, Sandberg DE, Grody WW, Nelson SF, Vilain E. Targeted massively parallel sequencing provides comprehensive genetic diagnosis for patients with disorders of sex development. Clin Genet 83: C35-C43, 2013.

76. MI, Tong YK, Yuen T, Jiang $\mathrm{P}$, Pina C, Chan KC, Khattab A, Liao GJ, Yau M, Kim SM, Chiu RW, Sun L, Zaidi M, Lo YM. Non-invasive prenatal diagnosis of congenital adrenal hyperplasia using cell-free fetal DNA in maternal plasma. J ClinEndocrinolMetab99: Ce1022C1030, 2014.

77. Looijenga LHJ, Hersmus R, de Leeuw BH, et al. Gonadal tumours and DSD. Best Pract Res ClinEndocrinolMetab 24: 291-310, 2010.

78. GB, Parra DA, Oudjhane K, Miller SF, Babyn PS, Pippi Salle FL. Imaging of ambiguous genitalia: classification and diagnostic approach. RadioGraphics. 28: C1891C1904, 2008.

79. Papaioannou G, Sebire NJ, McHugh K. Imaging of the unusual pediatric 'blastomas.' Cancer Imaging 9: C1C11, 2009.

80. M, Meyts RE, Andersson L, Dieckmann KP, Fosså SD, Grigor KM, Hendry, Herr HW, Looijenga LHJ, Oosterhuis JW, Skakkebaek NE. Carcinoma in situ in the testis. Scand J UrolNephrolSuppl 205: C166-C186, 2000.

81. Ramani P, Yeung CK, Habeebu SS. Testicular intratubular germ cell neoplasia in children and adults with intersex. Am J SurgPathol 17: C1124-C1133, 1993. 
Clinical Approach for Evaluation and Management of Disorders of Sex Development 